УДК 165.191:141.7 2-264 : [1 + 159]

DOI 10.35423/2078-8142.2018.3-4.12

М.В. Лукашенко, кандидат філософських наук, практичний психолог Вінницького медичного коледжу імені акад. Д. К. Заболотного, м. Вінниця, Украӥна

ORCID: https://orcid.org/0000-0001-5430-0808

\title{
ТРАНСФОРМАЦІЇ ВІДОБРАЖЕННЯ МІФІЧНОСТІ СВІТУ У ДЗЕРКАЛІ ФІЛОСОФІЇ І ПСИХОЛОГІЇ
}

У статті розглядається історично динамічне відображення феномена «зачаклованості» сочіального світу у міфологічних, філософських і наукових психологічних знаннях. На прикладі ставлення до міфів та їхнього місия у психологічних знаннях показано не лише співіснування та взаємний вплив різних парадигм знань, а й ииркуляція між ними інформації та методів роботи з нею. Спільно уявлені міфи від часів Когнітивної революиії до сьогодні створюють уявні реальності, які є умовою успішної співпраці людей у групах будь-яких розмірів. Розкриваються причини боротьби з міфами з метою "розчаклування» світу та одночасне виникнення їх нових форм. Сучасні міфи розглядаються з позицій соиіальності, ресурсів суспільства, психотерапії та ї̈ методів.

Ключові слова: міф, етапи розвитку психології, психотерапія, релігія, соиіальність.

Питання зачаклованості світу, його розчаклованості та появи нових модерних «чарів» цікавило як перших соціологів (М. Вебер, Е. Дюркгайм), так і сучасних соціальних мислителів (Т. Адорно, М. Горкгаймер, М. Маффесолі, Ч. Тейлор). Так, М. Вебер описав розчаклований модерний світ, божественне якого Е. Дюркгайм знаходив у самому соціальному, в силі, що поєднувала людей у суспільство. Проте Т. Адорно і М. Горкгаймер вже визнали створену просвітницькими міфами реальність за ще більше чаклунство, а М. Маффесолі вічну

(c) Лукашенко М. В., 2018 
«зачарованість», ірраціональність світу вбачає у духовній складності самих взаємовідносин між людьми.

Згадані бачення соціального світу пояснюються модерною вірою і постмодерною зневірою у прогресивній поетапності розвитку та ускладнення суспільства, світогляду людей, а також прагненням знайти правильні демаркаційні лінії між виокремленими періодами. На важливості визначення межі початку того чи іншого часу наголошував I. Валлерстайн, описуючи «тривале шістнадцяте століття», що поіншому визначає особливості «світ-системи Модерну», ніж коли початок модерного періоду пов'язують 3 наступними століттями.

Ілюстрацією поетапної стратегії історично-наукового мислення є формулювання О.Контом закону «трьох стадій», відповідно до якого у будь-якій науці можна виокремити теологічний, метафізичний і науковий періоди, коли кожна наступна стадія $є$ завершенням попередньої і суттєво відрізняється від неї. Розглянемо дану стадійність на прикладі соціально-психологічних знань. Із такої позиції міф уявлявся як «спрощена» форма донаукового сприйняття складного світу, а філософський період створив умови для розвитку наукового знання, етап якого почався зі зміни методології на природничо-наукову. Саме таке бачення дало М.Еббінгаузу можливість узагальнити, що психологія має тривале минуле, але досить коротку історію.

Подібне виокремлення трьох періодів розвитку психології (міфологічний, філософський і науковий), зустріло з боку частини фахівців методологів заперечення. Так, на думку М. С. Роговіна, всі три позиції формування психологічних знань, які він визначає як донаукову, філософську і наукову психологію, продовжують співіснувати та здійснювати взаємний вплив [5, с. 6]. Таке бачення можна порівняти 3 хвилями, що накривають одна одну на кшталт цивілізаційних хвиль Е. Тофлера. Доводячи дану тезу, як не остаточне зникнення властивих попереднім етапам світоглядних, методологічних та сутнісних їх особливостей, а як фонове існування з можливими флуктуаціями та новими інтерпретаціями, розглянемо кожний з означених періодів як у визначених історичних рамках, так і в сучасності, зокрема крізь призму змін ставлення до феномена міфів у світі.

Першим виокремлюється міфологічний, або теологічний, донауковий період розвитку психології. М. С. Роговін пов’язує його з пошу- 
ком та розвитком понять щодо діючих причин у житті людини, яка почала приписувати можливі інтерпретації буттю, основною формою чого стали міфи. Початком цього періоду вважається час близько 7030 тисяч років тому, коли відбулась Когнітивна революція, що характеризувалась появою нових способів мислення, типу мови та спілкування [9, с. 34]. Людина розумна вже володіла гнучкою мовою, яка забезпечує соціальну взаємодію, співпрацю і дає можливість передавати, отримувати інформацію про світ і своє місце у ньому, розповсюджувати плітки. Проте найголовнішою унікальною рисою людської мови Ю. Н. Харарі вважає «здатність передавати інформацію про речі, яких взагалі не існує», коли з'являються спільно уявлені легенди та міфи [9, с. 38]. Завдяки колективній уяві спільні міфи та віра в них створюють уявні реальності, які змінюють світ та дають умови для успішної співпраці у великих групах незнайомих людей. Такий внутрішній об'єднуючий принцип дав Б. Андерсену можливість описати модерний феномен націй як уявлені спільноти, що підтверджує тезу про не зникнення закономірностей, властивих попереднім етапам розвитку психологічних знань, а їх можливе ускладнення та зміни у філософській та науковій парадигмах.

Від періоду Осьового часу починається філософський період розвитку психологічних знань. За М. С. Роговіним для філософської психології властиво шукати пояснювальний принцип психічного та його загальні закони [5, с. 6]. Проте зв'язок соціального і міфологічного був і залишається таким щільним, що відчувався як розчинення, скрізь-присутність міфу у конструюванні соціальної реальності людьми. Тому час, який у згаданій періодизації психології названий «філософським», більше характеризувався прагненням відокремити реальне від примарного, справжнє буття від ілюзорного. Проте для міфологічної свідомості міф і є конкретною, максимально інтенсивною, напруженою реальністю, що має свою істинність (О. Лосєв). Відчуття такої справжності сформованої реальності пов'язано з людською потребою в орієнтації, описаною Е. Фромом, яка стимулює цікавість до пізнання та розуміння світу.

Розглядаючи історію психологіï крізь принцип вчинків, В. А. Роменець підкреслює відмінність першого міфологічного етапу від наступних через пізнання людиною самої себе. Спочатку вона пізнає себе через відокремлення від навколишнього світу, а на другому 
етапі розвитку психологічних знань - корелюючи з навколишнім світом, що відкриває з часом можливість шукати єдність психічних феноменів [6, с. 42-43]. Такий підхід дав можливість по-іншому описати етапи трансформацій історико-психологічних феноменів, зокрема як: «ситуацію значень: міфологічна і народна психологія», «ситуацію конфлікту: Стародавній світ», «ситуацію колізії: Середні віки», через «принцип мотивації: психологія Відродження», «принцип прийняття рішення: психологія епохи Просвітництва» $\mathrm{i}$ «образ людини» в академічному і колізійно-драматичному стилі (XIX-XX ст.).

За часів філософського періоду психології було створено широке поле психологічних знань, отриманих методом спостереження, інтроспекції, рефлексії та сформувалась ситуація готовності до зміни парадигми, появи нової методології і початку наукового етапу. Він був пов'язаний з визнанням, що зміни тенденцій розвитку суспільства залежать від змін мислення його членів і знаменувався боротьбою зі старими міфами. Хоча саме за часів Просвітництва окрім збереження частини традиційних міфів, активно продукувалися нові наукові, економічні, політичні міфи. Сьогодні ж знов актуалізується парадигма Просвітництва, хоча у новій його формі, з новими цінностями. Так, члени виконавчого комітету Римського клубу пишуть про необхідність нового Просвітництва, яке підходило б для всього «повного світу», про зміну напряму прогресу, про зміну гуманізму, який має перестати бути примітивно антропоцентричним [11].

Після войовничо-наукового періоду «полювання» на міф як на форму донаукової інтерпретації та пізнання світу, він знов повертається до методологічного тезаурусу дослідників, займаючи чільне місце в картині постмодерного бачення світу. 3 одного боку, Л. Вітгенштайн оголошує віру у сплетення причинно-наслідкових взаємозв'язків марновірством, коли за пошуком каузальності стоїть спрощення картини світу, а з іншого - міф Р.Бартом визначається як комунікативна система, форма соціальності. Іншими дослідниками міф визнається як засіб соціальної інтеграції людей, тим, що дає відчуття єдності, сягає колективного несвідомого (М. Маффесолі, Ж. Сорель, Ю. Н. Харарі), або навіть $є$ формою ідеології (П. Гуревич). Знаходить своє осмислення міф і як своєрідна форма свідомості (Фуркало) [7, с. 25]. 
Так, сьогодні констатується міфологічність свідомості, метафоричність мислення сучасної людини, нова зачаклованість світу. Про це свідчать не лише запити людей різного рівня освіченості та соціального статусу на отримання інформації від «спеціалістів» 3 паранормального (астрологи, шамани, гадалки, екстрасенси і т.п.), популярність фантастичних фільмів про надприродне, серіалів, телевізійних шоу, а й саме міфологічне сприйняття світу, наприклад, бізнескорпорацій, у яких юристи є «могутніми чаклунами» [9, с. 42-43].

Така міфологізація уявленого сучасного світу націй, держав, корпорацій тощо дає дослідникам можливість у парадигмі постсучасності розглядати міф не лише як фактор соціокультурних змін, а й як прагматичний ресурс майбутнього. Хоча $з$ позиції концепції міфів, сама постсучасність також є міфом. Так, Ю. Н. Харарі відзначає, що «оскільки масштабна співпраця людей базується на міфах, спосіб співпраці можна міняти шляхом зміни міфів - розповідаючи інші історії» [9, с. 48]. Тобто ставлення до міфу сьогодні розглядається 3 позиції його свідомого використання у сфері управлінських впливів. На державному рівні розглядається можливість регульованого відродження ролі міфічно-символічних конструкцій, традиційних міфологем 3 метою формування стимулу розвитку суспільства, застосування одночасно як механізмів міфотворення, так і деміфологізації, «за рахунок цілеспрямованого введення характеристик ідеального як об'єктивної реальності» [10, с. 21-24]. Легітимація використання міфу у суспільство-творенні та керуванні ним відбувається шляхом проголошення існування таких вимірів буття, які створюються, і які освоюються засобами міфу. Адже міфи мають як стимулюючий, так і стримуючий ефекти впливу на розвиток у певному напрямку з горизонту можливостей. Вони також зумовлюють динаміку трансформацій суспільства, що пов'язано з його історичною пам'яттю, традиційними та новітніми культурними кодами. Тобто боротьба за міфологеми минулого є результатом вибору стратегії досягнення бажаного майбутнього, адже міфи відчутно впливають на процес прийняття рішення, позицій та дій громадян.

У сучасній психотерапії також широко застосовується «спадок» 3 міфологічної та філософської психології. Наприклад, системною психотерапією у роботі з сім'ями як системами, сімейними історіями, міфами, симптомами, які розглядаються як метафоричний спосіб ко- 
мунікації. Зокрема, засвоюючи певний набір наративних моделей, людина вростає у культурний канон, але не всі історії, які ми про себе розповідаємо, які створюють нашу особистість, є ресурсними і тому потребують деконструкції (М. Уайт), а деструктивні внутрішні конструкти проблеми мають пройти екстерналізацію. Тобто міфологічність не знецінюється як «донауковість» і філософські методи широко використовуються у науковій психології.

Циркуляція ідей, методів між філософською, експериментальною і практичною психологією яскраво ілюструється на прикладі відображення соціальності у соціальній філософії, психології, соціології. Так, стан кризи соціальності в індивідуалізованому суспільстві описується у термінах «смерті соціального» (Ж. Бодріяр), його «трансформацій» та «трансфігурацій» (М. Маффесолі), коли наголошується на тому, що народжується нове на зміну тому, що зникає. Від періоду, коли перенасичення модерного суспільства структурами, які його скріплюють, досягло надміри, і їхня кількість та якість змінилась, перетворивши суспільство на постмодерне, змінюється характер соціальності. М. Маффесолі зауважує появу феномена трайбалізму як зростання кількості малих груп екзистенціальної мережі, який базується на локалізмі і має релігійний дух [3, с. 277]. Якщо, описуючи сучасне суспільство, З.Бауман визначальною його рисою обирає індивідуалізованість та плинність соціальних практик, то М. Маффесолі бачить ознаки завершення цивілізації, основаної на індивідуалізмі. Він наголошує на спільності чуття, що підштовхує людей до об'єднань, локальних варіантів солідарності, скріплених «громадянською релігією», однією пристрастю, ідентифікованою особою якої може стати зірка, спортивна команда тощо. Нові інформаційні мережі багато в чому відновлюють і посилюють зв'язок між людьми, пристрасть до надзвичайного в таких групах, розповсюдження спільного міфу.

Тут варто згадати значення терміна «religio», як відновлення зв'язку. Проте і для психології та психотерапії одним з основних завдань $є$ встановлення внутрішньо-особистісного, інтерсуб'єктивного, соціального зв'язків. Психотерапію можна розглядати як лікувальний вплив слова на психіку, а через неї - на весь організм людини, а можна як і лікування душі («психо» - душа). Але у будь-якому випадку це лікування стосунками, тим, що відбувається «між»: між терапевтом і 
клієнтом, між членами групи, між людиною і Богом (коли християнство розглядається як медична наука [1, с. 18]). Саме сфера «між» визначається діалогічно спрямованими філософами як найбільш значуща, в якій народжуються ідеї, яка є місцем спів-буття, спів-творчості, народження етики. Хоча первинне значення етики відображає місце перебування людини, яке і є простором присутності Бога [8, с. 348].

Зв’язки один 3 одним і з Богом мають доцентрово-вертикальний i спільний горизонтальний рівень, що притаманно койнонії. Цей феномен сьогодні розглядається як причастя людини і спільноти до Бога та як природна і надприродна спільність людей один одному у Бозі [2]. Певна спільність койнонії та психотерапевтичних груп створила умови для повернення практичної психології 3 iї інструментарієм у життя релігійних спільнот. Йдеться про повернення, адже початок наукового періоду, який визначається зміною методології на природничу, пов'язаний 3 Київською духовною академією, де у 1862 р. М. Троїцьким при кафедрі психології була створена перша в світі психологічна лабораторія. Сьогодні ж нові релігійні спільноти (наприклад, молодіжні групи «Молодь не байдужа» в Українській Православній Церкві, рух неокатехуменату у Католицькій Церкві) послуговуються психологічним інструментарієм групової психотерапії, Т-груп тощо.

У ювілейній доповіді Римського клубу, посилаючись на слова Папи Франциска, червоною лінією проходить ідея кризи, зокрема i цінностей, і філософської думки, сучасних переконань, які формувалися за часів «пустого світу». Підіймається питання висвітлення в ЗМІ позитивної ролі релігій, визнання впливу християнства на соціальну солідарність, вибудовування системи «західних цінностей», що лежать в основі держави всезагального добробуту [11]. Епохальна праця E. Вайнзеккера i A. Війкмана «Come On! Капіталізм, короткозорість, населення і руйнування планети» у самій назві містить натяк на дві позиції розгляду сучасної ситуації кризи. Перша відображає розмовне значення «C'mon» («не намагайся обманути мене») і свідчить про усвідомлення та протидію звичним описам дійсності та порадам, які не здатні зробити світ краще, застарілим доктринам. Друга - «Come on» («приєднуйся до нас») - висвітлює реальні рішення та варіанти виходу iз сучасної ситуації кризи. 
Певним чином дана доповідь перегукується з іншим, достатньо категоричним і традиціоналістичним, документом - Паризькою декларацією «Європа, в яку можна вірити», яка була оприлюднена у жовтні 2017 р. У ній європейськими мислителями констатується, що спільна батьківщина перебуває в кризі, викликаній станом розуму і уяви, хибним розумінням себе і своєї історії, ідеологічними перверзіями і розтриньканням цивілізаційної спадщини. У ній позиціонуються тезиси щодо відродження автентичної Свропи, відмови від «фальшивого» прототипу «універсальної спільноти, яка насправді не є ні універсальною, ні спільнотою», повернення до християнських ідеалів, коренів, на відміну від «сентиментів псевдорелігійного універсалізму», відновлення національної єдності і солідарності [4]. Тобто сьогодні на суспільному рівні підіймається питання місця релігії у суспільному розвитку. Як пов’язана подібна увага із сучасною соціальністю?

Одним із соціально помітних аспектів відмінностей у контексті життя людей, які є членами певної християнської спільноти, є сотеріологічний, який визначає різне бачення горизонтів майбутнього та того, що чекає за ними, надання трансцендентному майбутньому іншого значення. Симптомом же сучасності є прагнення концентруватися на переживаннях «тут і тепер», зменшуючи значення планів та цілей, які виглядають невизначеними у плинному бутті сьогодення, а також відсутність мети, яка виходила б за межі буття. Іншим наслідком орієнтованості сучасної людини на «тут і тепер» $є$ зміна домінанти з раціонального, спрямованого на прогрес інтелекту, на його емоційну форму та інгрес (М. Маффесолі). Симптомами таких змін є не лише збільшення моделей клінічних розладів психоемоційної сфери та епідемічне розповсюдження деструктивних станів (наприклад, депресія як одна з основних причин непрацездатності), а й поява емоційно-фокусованих психотерапевтичних напрямів, зокрема подружньої терапії (С. Джонсон, Л. Грінберг), філософських та богословських праць, в основі парадигм яких лежать емоції та почуття, естетичні переживання (Д. Гарт), вивчення емоційного інтелекту.

Проаналізувавши етапи розвитку психологічних знань крізь призму відображення їх перших міфічних форм у наступних парадигмах, можна зробити висновок не лише про не зникнення міфів, а й про новий розвиток та свідоме використання. Тобто сьогодні поділ на міфо- 
логічні, філософські та наукові психологічні знання має історичний характер, відображає трансформації методології, проте $є$ умовним, адже між ними відбувається постійна циркуляція інформації та методів. Так, філософська психологія узагальнює знання, отримані експериментальною, а практична психологія, психотерапія інтегрує філософські методи. А міфи сьогодні перестали бути лише об'єктами наукового вивчення, вони стали частиною практичної соціальнопсихологічної методологї̈.

\section{ЛІТЕРАТУРА}

1. Влахос И. Православная психотерапия: святоотеческий курс врачевания души / Митрополит Иерофей (Влахос). Свято-Троицкая Сергиева Лавра, 2005. 368 с.

2. Іиук Н.В. Літургія як здійснена койнонія // Вісник Львівського університету. Серія філософсько-політологічні студії. 2017. Вип. 12. С. 67-73.

3. Маффесоли М. Околдованность мира или божественное социальное // СОЦИО-ЛОГОС. М. : Прогресс, 1991. С. 274-283.

4. Паризька декларація: «Європа, в яку можна вірити» [Електронный pecypc]. Збруч, 6.11.2017. [Електронний ресурс]: Режим доступу: https://zbruc.eu/node/72673

5. Роговин M. С. Элементы общей и патологической психологии в построении психологической теории [Текст] : автореферат дисертации дра педагогических наук. М, 1968. 28 с.

6. Роменець B. A. Історія психології. Стародавній світ. Середні віки. Відродження. К. : Либідь, 2005. 915 с.

7. Фуркало В. I. Міфологічний аспект ідеї соціальної справедливості // Мультиверсум. Філософський альманах. 2012. № 10 (118). С. 24-32.

8. Хайдегzер M. Письмо о гуманизме // Проблема человека в западной философии. Москва, 1988. С. 348-350.

9. Харарі Ю.Н. Людина розумна. Історія людства від минулого до майбутнього. Харків: Клуб сімейного дозвілля, 2018. 543 с.

10. Шедяков B.C. Міфічність розвитку contra використання міфу з метою розвитку // Мультиверсум. Філософський альманах. 2013. № 3 (121). C. 21-30.

11. Weizsacker E.U., Wijkman A. Come On! Capitalism, Shorttermism, Population and Destruction of the Planet - A Report to the Club of 
Rome / Ernst Ulrich von Weizsacker, Anders Wijkman. NY : Springer Science+Business Media LLC, 2018. - 220 p.

\section{REFERENCES}

Vlachos, I. (2005). Orthodox psychotherapy: the patristic course of healing the soul. Holy Trinity St. Sergius Lavra. [In Russian].

Ischuk, N. V. (2017). Liturgy as a realized koinonia. Visnyk of Lviv National University. A series of philosophical-political studies, Vip. 12, 67-73. [In Ukrainian].

Maffesoli, M. (1991). The spell of the world or the divine social. SOCIOLOGOS. Moscow: Progress, 274-283. [In Russian].

The Paris Declaration: A Europe that can be trusted. (2017). Retrieved from https://zbruc.eu/node/72673

Rogovin, M. S. (1968). Elements of general and pathological psychology in the construction of psychological theory (Abstract of the dissertation of Dr. pedagogical sciences). Moscow. [In Russian].

Romenets, V. A. (2005). History of psychology. The ancient world. Middle Ages. Renaissance. Kyiv: Libid. [In Ukrainian].

Furkalo, V. I. (2012). The mythological aspect of the idea of social justice. Multiversum. Philosophical almanac, No. 10 (118), 24-32. [In Ukrainian].

Heidegger, M. A. (1988). Letter on Humanism. The Problem of Man in Western Philosophy. Moscow. [In Russian].

Harari, Yu. N. (2018). The person is smart. The history of mankind from the past to the future. Kharkiv: Family Leisure Club. [In Ukrainian].

Shedyakov, V. E. (2013). Mythical development of contra use of myth for the purpose of development. Multiversum. Philosophical almanac, № 3(121), 21 30. [In Ukrainian].

Weizsacker, E. U., Wijkman A. (2018). Come On! Capitalism, Short-termism, Population and Destruction of the Planet. A Report to the Club of Rome. NY: Springer Science + Business Media LLC. 


\section{Lukashenko Maryna}

Candidate of Philosophical Sciences (Ph. D.), Practical Psychologist, Vinnitsa Medical College, Vinnitsa, Ukraine, ORCID: https://orcid.org/0000-00015430-0808

\section{Transformations of mithicity of the world image in philosophy and psycholo- gy}

\section{Abstract}

The article deals with the historically dynamic reflection of the phenomenon of the social world conception in mythological, philosophical and scientific psychological knowledge. For example, the attitude toward myths and their place in psychological knowledge shows not only the coexistence and mutual influence different paradigms of knowledge, but also the circulation of information and methods of work. The author notes that during the philosophical period of psychology a wide field of psychological knowledge, obtained by the method of observation, introspection, reflection, was created, and a situation of readiness to change the paradigm, the emergence of a new methodology and the beginning of the scientific stage were formed. He was associated with the recognition that changes in social development tend to depend on changes in the thinking of its members and was marked by the struggle against old myths. Although it was during the Enlightenment, in addition to preserving some of the traditional myths, new scientific, economic and political myths were actively produced. Today, however, the Enlightenment paradigm is being updated again, albeit in its new form, with new values. Jointly presented myths from the time of the Cognitive Revolution to today create imaginary realities that are a prerequisite for the successful cooperation of people in groups of any size. The reasons for struggling against myths and the appearance of their new forms were described. It is noted that today the division into mythological, philosophical and scientific psychological knowledge has a historical character, reflects the transformation of methodology, but it is conditional, since there is a constant circulation of information and methods between them. Thus, philosophical psychology generalizes the knowledge obtained experimentally, and practical psy- 
chology, psychotherapy integrates philosophical methods. And today myths have ceased to be objects of scientific study, they have become part of a practical socio-psychological methodology. Modern myths are considered from the point of view of sociality, society's resources, psychotherapy and its methods.

Keywords: myth, stages of development of psychology, psychotherapy, religion, sociality.

\section{Лукашенко Марина}

кандидат философских наук, практический психолог, Винницкий медицинский колледж имени акад. Д.К. Заболотного, г. Винница, Украина, ORCID: https://orcid.org/0000-0001-5430-0808

\section{Трансформации отображения мифичности мира в зеркале философии и психологии}

\section{Аннотация}

B статье рассматривается исторически динамическое отображение феномена «заколдованности» сочиального мира в мифологических, философских и научных психологических знаниях. На примере отношения $к$ мифам и их места в психологических знаниях показано не только сосуществование и взаимное влияние различных парадигм знаний, но и цииркуляция между ними информации и методов работьл с ней. Совместно представленные мифы со времен Когнитивной револючии до наших дней создают мнимые реальности, которые являются условием успешного сотрудничества людей в группах любых размеров. Раскрываются причины борьбы с мифами с иелью "расколдовывание» мира и одновременное возникновение их новых форм. Современные мифы рассматриваются с позищий социальности, ресурсов общества, психотерапии и ее методов.

Ключевые слова: миф, этапь развития психологии, психотерапия, религия, сочиальность 